\title{
THE BIODIVERSITY CONSERVATION IN THE COASTAL ECOSYSTEMS OF THE TABASCO State, Mexico as Sustainable Response again Climate Change EfFects
}

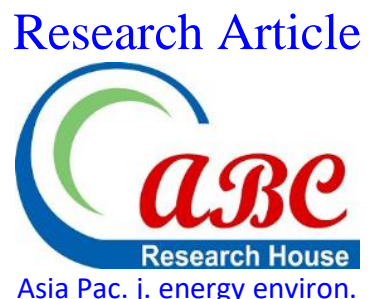

Asia Pac. j. energy environ.

\author{
Silvia Domínguez Parra* \\ *Email for Correspondence: cambioclimaticodaad@gmail.com
}

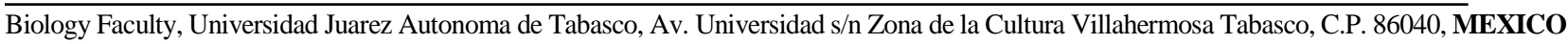

Abstract

The Conservation of the Biodiversity in accordance with the Program of Environment of United Nations (UNEP) cannot be limited to a matter of geographical borders, in many cases it must be studied like regional interpretation or global initiative. In this context, the environmental models and the information obtained with the use of the skills of remote sensors and application of geographical information systems to evaluate the Biodiversity Conservation represent important instruments, in order to take to good term the proposals like studies, projects, plans of regional management. In Mexico applications of these technologies exist already, in particular this work refers the efforts to apply them in the coastal zone of Tabasco State, Mexico, which it is extensive, also characterized by a great Biodiversity like: wealth lands, tropical vegetation and animals species located in the coastal lagoons, estuaries ecosystems, which has not been well evaluated yet and which study is necessary to realize in order to carry out conservation and protection programs adapted for these ecosystems. This work shows the Tabasco government and its inhabitants relative to know the possibly effects that the Tabasco coastal zone is suffering in its Biodiversity composition, due to the actions of the Climate Change, other natural reagents (hurricanes, tropical storms, etc.) and those activities derivates of human causes for which it consider a specially methodology as the use of remote sensors and geographical information systems to obtain Biodiversity models at regional scales.

Key words

Biodiversity, Conservation, Climate Change, GIS, environmental planning

\section{INTRODUCTION}

The worry for attending to problems of conservation of the natural resources and its relations with the productive processes, we can say that it occurred from the 80s, when the United Nations Organization impelled the World Commission of the Environment and of the better Development known as the Commission Brundtland, group that was employed at topics of economic, social and environmental development and gave like turned out the report Our best Future in which it introduced for the first time the development concept sustaintable, years later in the Conference on Environment and Development in Rio de Janeiro achieved to sign the Agreement on Biological Diversity the Convention marked with the United Nations on Climate change and the Agenda XXI, from these efforts there have existed other meetings internments as the meeting of Davos, Switzerland the year 2009 on Climate Change and the one that was celebrated the year 2010 in Cancun, Quintana Roo where the topic of the protection and conservation of the Biodiversity stands out like a general worry of all the governments of the world. We live at present through a critical time for the future of the Biodiversity and Humanity. The phenomenon of Global Climate Change that today experiences our planet is a limiting factor for the Conservation of the Biodiversity. The UNEP, 2010 has expressed the need to think about the Environmental Services that the nature provides to the Humanity like priority, for this reason all countries must planned economic resources for the maintenance, conservation and rehabilitation of ecosystems and its biodiversity, especially in those countries in which their societies have impacted the environment and its resources. 
In accordance with recent reports the coastal phytoplankton could be absorbing half of greenhouse gases, derivatives of terrestrial transport UNEP 2010. This organization thinks that the countries of our world should consider to the Biodiversity Conservation as a priority, because it involves the survival of all life in this planet.

Mexico, is a country gentle diversely, it occupies the third place for its biodiversity (Conabio, 2001). Inside the different ecosystems that they characterize to Mexico there are the coastal zones, which occupy an important place for its extension. According with Reid, 1988 they constitute very diverse ecosystems and are characterized by the interaction of terrestrial and marine systems, there are transition areas, where the ecological, geologic and biological factors coexist. These zones were characterized by Reid for its fragility and very important natural resources. The coastal zone constitutes the thin and fragile interface between three extensive means: the environment, the ocean, and the continent. Any change in these will have necessarily an effect on the coastal zone. The coast is been continuing form by the combination of the dynamics of the same ones. The Climate Change produces actions in three means; therefore it affects the coastal zone. If the changes mentioned before produced effects in the Biodiversity composition, it is necessary to know how expense were. A phenomenon can acts in a big time scale. It can be accelerated by human activities. It needs know how the alterations in the Biodiversity structure were or adaptations occurred. The changes in the climate it is a phenomenon that it is in the environment, as a result of variabilities in the dynamics of parameters as: the winds, currents, the temperatures and the precipitations. Each of these factors has its self influence on modellers parameters of the coastal zone: since there are the thunderstorms, the average level of the sea and the wealth of the rivers (Saizar, 1996).

The Tabasco state is provided with an extensive coast, has a wealth fauna and flora in its coastal lagoons co systems that has not been well evaluated. This study look for to collected the basic and inter media data that can be used for other researchers or authorities in order to implement programs conservation and protection adapted of these ecosystems.

In the last three decades was increased human establishments in the Tabasco state, simultaneously, the regional economy grew and with it the pressure towards the use of terrestrial, marine, forest natural resources. Have been observed that a decrease of the natural areas caused by soil use change. The coastal zones of Tabasco state have experienced changes caused by the not sustainable use of its resources, occurring of natural events (hurricanes, floods, tides, currents, etc.), as well as for the constant arrival of different pollutants derived from socioeconomic activities (agriculture, cattle, fishing, etc.) characterized by the extensive cattle, that produced the elimination of the fertile soil layer, favoring the gas formation greenhouse (Carabias, 2008). The agricultural activities with the employment of herbicides and pesticides reach port across poisonous pollutant surface washings for the coastal ecosystems. On the other hand, the activities derived from the oil industry also have helped to exercise a pressure raised in the coastal lagoons biodiversity of the Tabasco state.

According with the study presented by Díaz (2005) relative to environmental policy for the sustainable development of the coastal zones and the oceans in Mexico, there is glimpsed the need to regulate the coastal zone of the country. He observed, in the last years a major population growth $(2.3 \%)$ in these areas and also, the settle of important socioeconomic activities (petroleum activity, industry of the cement, mining, cattle, fishing, tourist, etc.). This author suggests the need to realize an ecological arranging of the coastal zone at national, state and municipal level.

This project also have the objective of evaluate and to determine the state that keep the coastal ecosystems of Tabasco State of Tabasco including the structure and composition their Biodiversity, detection the natural recourses conservation or alteration grade themselves, that they suffer actually by the climate change and other natural agents or human causes. It considered for this study a methodology that permit obtain environmental models apply to Biodiversity, and its data can do the development of management plans with ecological arranging or current public environmental policies that can use for their protection and conservation. The methodology that will be used in this study has demonstrated to be especially useful to attend to regional aspects of the Biodiversity (Busby et. 1999, Hunsaker et. to. 2001, Skidmore, 2002 Domínguez, 2009a).

\section{ObJectives OF THE Study}

The first intention of this project is to determine the current situation of the biodiversity of the coastal lagoon ecosystems of the state of Tabasco, determination a methodology that allows at regional level to use sustainable indicators (ONU, 2001). For attend this problematic will be needed collected the existing data and collected new information with the application of skills of remote sensing (remote sensors) and of geographical information systems. The particular objectives are depicted bellow:

- To create monitoring network to obtain environmental information, physicochemical, biological (Biodiversity, natural resources), chemistry, oceanographic, hydrologic, geologic, etc. parameters. To look for financing resources for this project across infrastructure donation for laboratory and the equipment of field. 
- To establish agreements with Mexican and German Universities for supported a Network of Biodiversity like the DAAD (Deutsche Akademische Austausch Dienst) to achieve methodologies exchange of knowledge obtain in this project.

- To realize supported to graduate programs and academic activities of formation of human resources with the achievement of Seminars, special Courses, and stays of research abroad.

- To promote extension universitaries activities as Conferences, participation of national or international Symposium, as well as to obtain of publications of national or international arbitration.

- To create or to encourage the creation of network experts' in Biodiversity applied to the field of Marine Sciences in Mexico that exchange of specializing information and for the support to the research, teaching and attention to problems of institutions of Federal or State Government.

\section{JUSTIFICATION}

In last year 1999, 2005 the State of Tabasco has suffered in its territory serious damages provoked by floods, caused by the arrival of tropical storms, hurricanes, big surface washings proceeding from the State of Chiapas, which impressed hard the coastal of Tabasco State and enclosed to the population, industrial, urban and agricultural infrastructure, media: TV/radio commercial, cattle with the consistent damage in the familiar and local economy of the state, causing also population mobilizations, provoking big losses in the cattle and agriculture. These damages can be explained by effects caused by the climate change that is being accelerated by the intervention of the productive processes of our society. These activities caused an increase of the greenhouse gases which in an indirect way are provoking the elevation in the sea level in the coastal zones, for which in accordance with Tinus, 1987 the coasts lines are subject to its erosion, floods, changes in the rains boss, salt of grounds, alteration of the phreatic cloak, and changes in the structure and distribution of the coastal ecosystems. In addition to this, it is important to mention the damages that the populations of coastal cities suffer with the impact of tropical storms or hurricanes, causing losses in urban, commercial infrastructure or loss in some cases of human lives. The Tabasco state, in accordance with Hernández et. al, 2007.theDay-school its worry for these events, for which it has happened to the task of protecting some studies that could describe these changes in the coastal of Tabasco State. Nevertheless, the studies realized till now, they have been only partial information, including geologic aspects, physical and biological, punctual parameters, without they having an of integration vision, which allows to know the current problems for the biodiversity located in coastal lagoon ecosystems, estimations that should point towards the future in accordance with methodologies established for (ONU, 2001) that could serve as instruments for governmental instances in the decision making to prepare programs of environmental management, ecological arranging and 1 risk.

\section{STUdY AREA}

The area is located in accordance with Hernandez et. to., 2008 between the $92^{\circ} 28^{\prime}$ and $94^{\circ} 10^{\circ}$ longitude west approximately and the $17^{\circ} 15^{\circ}$ and the $18^{\circ} 39^{\circ}$ of north latitude, located in the south region - southeast of Mexico limited by the Campeche state and on the west for the state of Veracruz. Natural limits to the north $191 \mathrm{~km}$ of coast or coastal zone in some parts on the south Saint Peter and San Pablo locate the rivers Mezcalapa, Pichucalco, Chacamar, Usumacinta, to the east for the rivers to the North-East for the river Tonala. Fig.1.

Geology: The coastal area has extensive low and very high plains, with earrings lower than 0.5 or 0.6 meter and of accumulative character in accordance with Hernández et. al. 2008, genetic fluvial sediments constituted by deposits of the quaternary recent one (sand, clays, slime) on sockets of tertiary calcareous rock. The coastal line is formed by foreshores and sand principally sometimes with presence of barrier islands that they shut up to the coastal lagoons as: Carmen, Pajonal, Machona, Tupilco, Three Palms, The Glories, Mecoa can, and others of less extension.

Climate: Humid tropical characterized by annual precipitation from 15000 to 2000 mm (Vidal 1990 in Hernández et. to., 2008), top annual average Temperatures to $26^{\circ} \mathrm{C}$ (García et. al. 1990) with minimal external values from $20^{\circ}$ to $22^{0}$ $\mathrm{C}$ in January and maximum between $30^{\circ}-34^{0}$ C.In May (García and Vidal $1990 \mathrm{~b}$ in Hernández et. al., 2008), in the last years nearby extreme values have been reached to $40^{\circ} \mathrm{C}$, predominant Diet of strong winds between 4 and $6 \mathrm{~m} / \mathrm{seg}$. sometimes higher than $8 \mathrm{mg} / \mathrm{seg}$. (Pérez Villegas, 1990b in Hernández et. al., 2008).

Main Hydrographic systems are the basins of the river Grijalva and Usumacinta, big mobility and migration appear determined by its hanging dweebs in its plains and for the abundant surface washings proceeding from the North of Chiapas State. In general the territory presents annual average surface washing between $1000 \mathrm{y} 2000 \mathrm{~mm}$ principally from July to December.

Soils: There are uniforms constituted for glysoles with hidromorfics external properties (López, 1990), another type of soils that compose the plains is the clayish soils and of slow drainage or that the marshes the sun compose the soils glysols, solonchak and vertisols (Inegi, 2007). Figure1. 
Vegetation: The region of beaches and coast characterized for aquatic and sub aquatic vegetation as well as sectors of tropical forests (Rezewdski, 1990). In the sub province of flatness and marshes with other characteristics vegetation of this zone. Between the communities of vegetation of the coastal zones there stand out the marshes located in flooded, slightly deep areas this vegetation is located in the freightage later to the coastal drawstring about the lagoons that spread parallel to the coast. The existence of the swamp depends on the conditions of flood and of presence of nutrients: In Tabasco State exist three mangrove species: Red mangrove (Rhizophora mangrove L), white mangrove (Lagunculana racemod (L.) Gaerth) and blackish mangrove (Avecennia germanans, (L) (L) (Garcìa and Palm, 1998).Their marshes are associations of aquatic, subaquatic and hydrophilous plants that are distributed in the deltas of the rivers, lagoons and estuaries that constitute parallel areas of the rivers Usumacinta Grijalva, Chacamax, Saint Peter. The biggest marshes extension locates in the reservation of the Biosphere of Marshes in Centla hat a 302,706 hectares approximate surface and is located in the municipalities of Centla, Jonuta and Macuspana.

Tides, Currents: The tides diet has been described extensively by Fernández et. at. 1990.

Along the Mexican coast of the Gulf of Mexico changes exist in the diet of swell determined by tropical storms, hurricanes, cold fronts and winds of the North-East. The waves reach from 1.4 to $2.3 \mathrm{~m}$ high generated except for the provoked ones by hurricanes and cold fronts that can come to $4.5 \mathrm{~m}$ (Lankford, 1977).

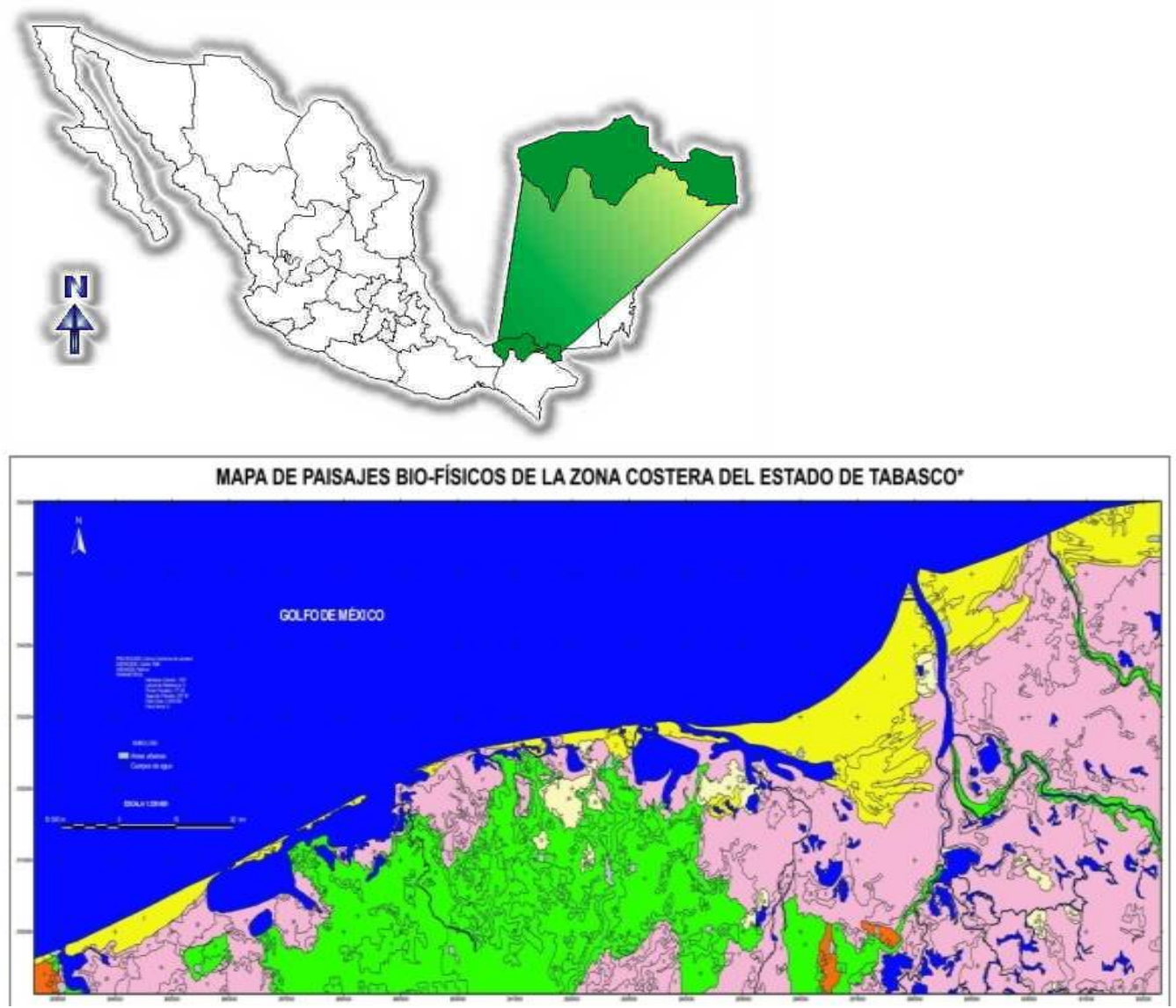

Figure 1: Map prepared Autonomous National University of Mexico

Institute of Geology. Academic Unit of Morelia. Project SEMARNAT 2001-CO1-0133. Modified of the Map physical - Geographical Sceneries prepared by Division of Biological Sciences of the University Juarez Autonoma of Tabasco (2006)

\section{Methodology}

The geographical information data of the distribution of wild life populations constitutes basic information for the management and protection of the biodiversity. Often the information source of the distribution stems from field remarks of the different species, the use of skills of radiometry and remote sensing these distribution records have been brought to apply in several species and they have resulted from big scientific value (Thouless and Dyler, 1992). Fig. 1.

Aerial Photographies have been used to take distribution records of several taxonomic groups, like mammals (Norton-Griffits, 1978), birds (Drewien et. al., 1996; Butler et.al., 1995); turtles and marine mammals (Wamukoya et. to., 1995), this way also for distribution maps of colonies of species like birds (Woodworth et. al., 1997) and shellfish (Neehls and Thiels, 1993. 
The Geographical information systems have resulted from big help to do maps or layers of information relative to the plenty and distribution of wild species have integrated the use of aerial photographies and also the use of images satelitales that have served for this intention bringing successful applications (Butler et. al the, 1995; Said et. to the, 1997, Domínguez, 2009b). Murphy et. al., 1998, it prepared maps and models of 9 classes of coral reefs using aerial photography's and images obtained with remote sensors, Figure 2.

There exist many other applications where have been emphasized the success of the use of these methodologies to be used in distribution and to evaluated the biodiversity and they allow to determine when a species is restricted why its ecological environmental to been altered by some external factor (pollutant, climate change, natural factors, etc.).Due to these characteristics to chose use this methodology in this project, across which an environmental model will prepare sustainable measurements for the protection of the existing biodiversity in the field of study, the same one will consist information layers across the use technologies of remote sensing and geographical information systems, once there had integrated goal information represented by the following information of parameters of physical environment, climatology, soil, vegetation, biodiversity (plenty and distribution of predominant species fauna and wild flora). Prins and Olff, 1998; Prins and Henne, 1998., have reported their use in the determination of socio economic parameters, also their interpretation with other physicochemical chemical parameters as pollutants, etc. Also, could obtain more representations of other variables if it is were necessary for the study with the use these technologies (ONU, 2001), Figure 3.

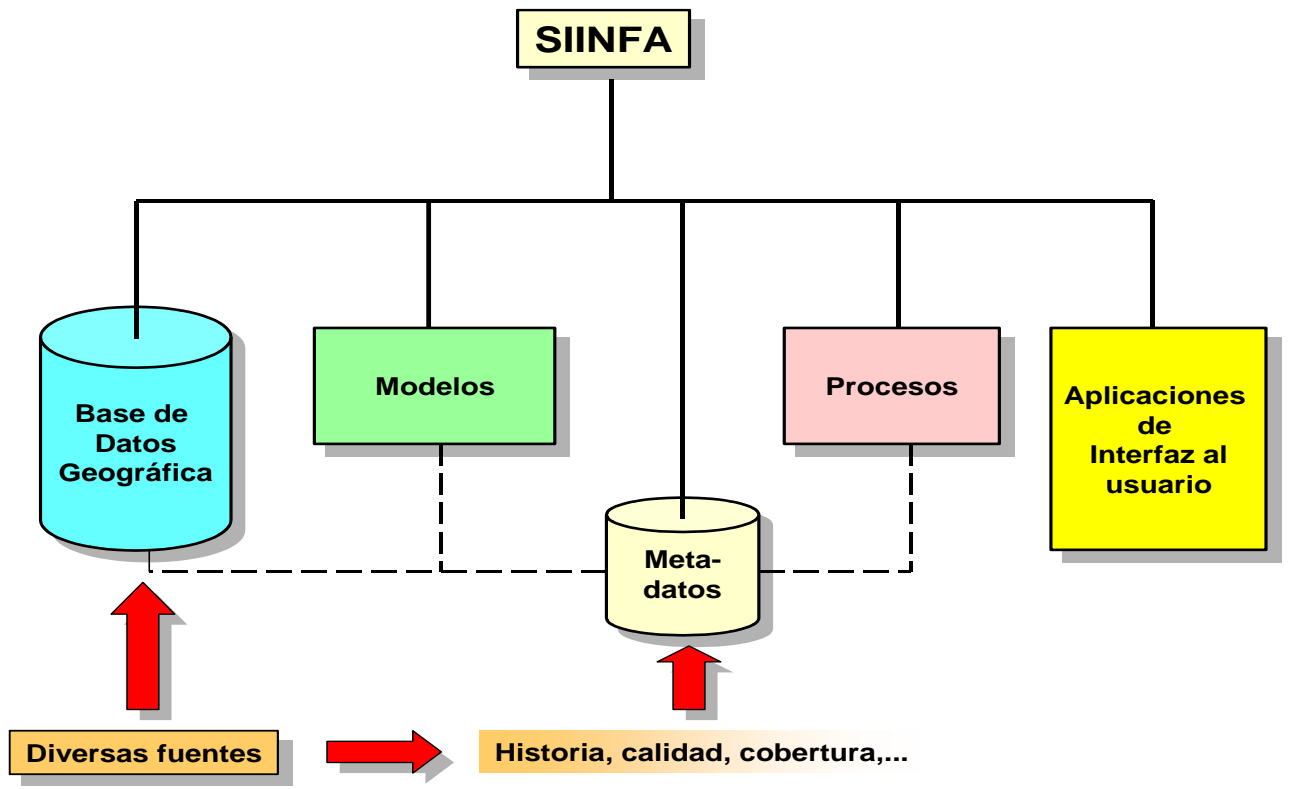

Figure 2: Geographical Information System of Environmental Applications

Data Bases: Biodiversity, Geography, Coastal Resources of Tabasco State, Enviromental parameters, Economic Activities, Sociologic factors, Demography, Study Area data, Environmental impacts, Environmental Risk, Mitigation Projetcs.Biodiversity evaluation. Productive Activities: Agricultural, stockbreeders, fishing, industries, etc.

\section{GoALS}

Short term

- To prepare work Program

- To determine needs of team and materials for its acquisition.

- To detection of support for technical personnel and human resources

- To sign Agreements or Ties with Mexican and German Universities.

- Sources of Financing for National project and foreigner.

- To establish Binnacle for the achievement of the project.

- To determine need for compilation and Goal securing information.

Average- Term

- To establish monitoring network.

- To prepare database.

- Look for international cooperation for support to project (visit of investigative specialist, stay abroad).

- Financing across Network of Biodiversity German Service of Academic Exchange (DAAD)

- Acquisition of laboratory Infrastructure and equip with cross-country German Service of Academic Exchange (DAAD). 
Long term

- Making of Environmental Model for the Management and protection the coastal biodiversity of the State of Tabasco.

- Extension universitary activities achievement across participation in congresses, Syimposium, do interview, etc. to announce the project its advances and results.

- To promote the establishment of specialists' Network in Biodiversity in coastal resources at national level.

- Making of publications and national and international arbitration.

- To promote the establishment of Specialists' Network in Biodiversity in Coastal Resources at national and International Level.

- To support across consultancies to institutions, federal, state, etc. interested in the project or problems to that the same one could attend.

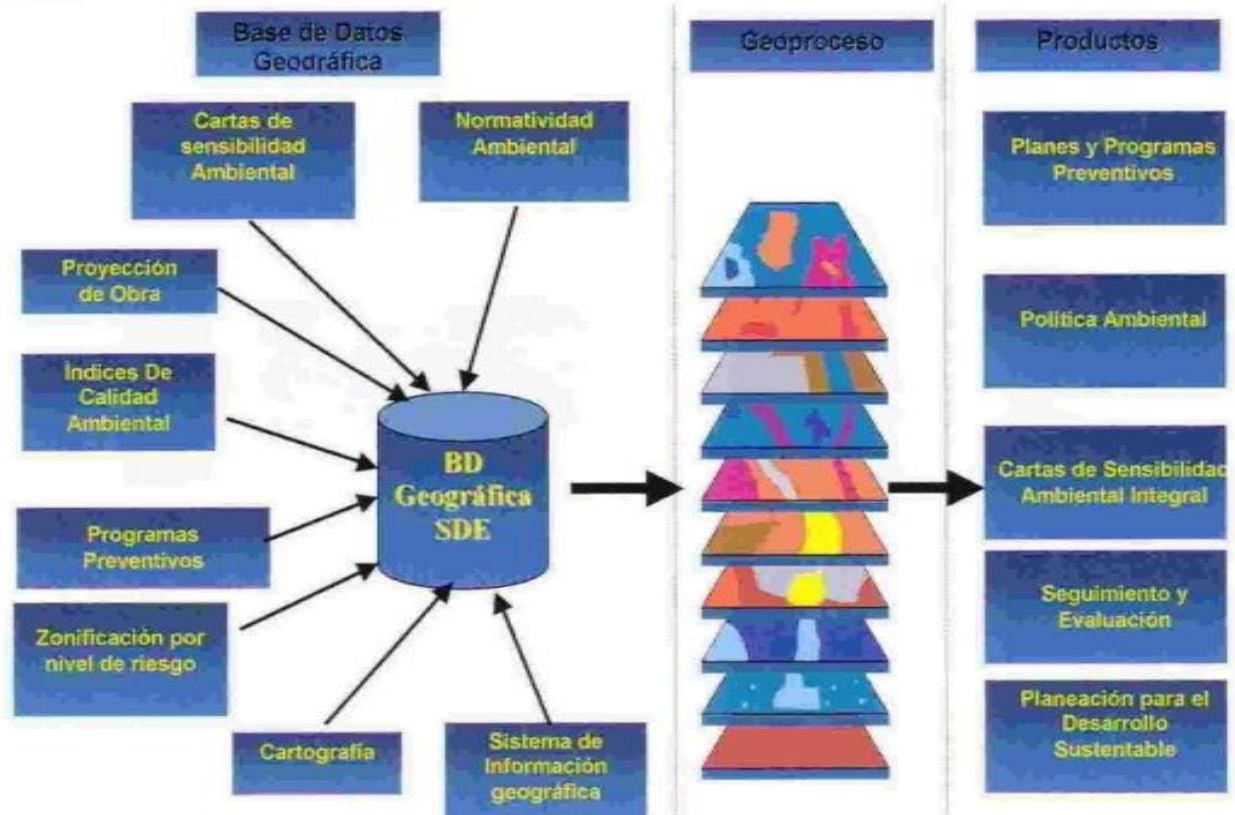

Figure 3: Inputs and Products with the use of geographic information system and remote sensors for Ecological planning for Protection or conservation Program of the Biodiversity

\section{REFERENCES}

\section{Journal Articles}

Beatly T. 1991.Protecting Biodiversity in coastal environment introduction an overview: Coastal Manag.19:1-19.

Butler R.W.and Kaiser, G.W.1995. Migration ceonology sex radio and body mas on least sand pipers in Brithish Columbia. Willson 3.Bull.107, 413-422.

Drewein RL. Brown W.M. and Benning. D.S. 1998. Distriburion abundance of sand hil cranes in Mexico. Journal of Wildlife Management 60, 270-285.4.

Mumby P.S. Green E.P. Edwards A.J. and Clark C.D. 1998 a. Coral reef habitat mapping: How much details can remote sensing provide.Marine Biology, 130, 193-202.5. 5.

Mumby. P.J. Clark C.D., Green. E.P. and Edwards A.J. 1998b. Benefit of water column correction and contextual editing for mapping coral reefs. International Journal of Remote Sensing. 19: 203-210.

Myers, N. 1988. Threatened biotas:"hotspots" in tropical forest. Environment.8 (3):1-20.

Nelhs G. and Thiels M. 1993. Large scale distribution patterns of the mussel mytilus edulus in the Wadden Sea of SchleswigHolstein: do storms structure the ecosystem. Netherlands Journal of Sea Research 31,181-187.

Ortiz, Pérez M.A. 1992. Retroceso reciente de la linea de costa del frente deltaico del río San Pedro Campeche, Tabasco, Investigaciones Geograficas. Boletín no. 25. Instituto de Geografía, UNAM, México, pp. 7-25.

Pannier, F. 1992. El ecosistema manglar como indicador de cambios globales en la zona costera tropical. Ciencia. 43. esp. 111-113.

Prins HH and Olff H. 1998. Species richness of African grazer assemblages: towards a functional explanation. In: D.M. Nowberg H.H.T. Prins and N.P. Brown (ed) Dynamics of tropical communities BES Symposium, 449-490.Oxford Blackwell Scientific.

Psuty, N.P.1965 Beach-Ridge. Development in Tabasco. Annals of the Assocition of American Geographers. México pp43-54.

Reid, W.V, K.R. Miller. 1989. Keeping option alive: The scientific basis for conserving biodiversity. World Resour. Inst. Washington.D.C.110 p,

Rezewdski, J.1990."Vegetación Potencial”: Atlas Nacional de México. Hoja IV: 8.2. Instituto de Geografía UNAM, México.

Said, M.Y. Ottichilo, W.K., Sinange, R.K. and Aligula, H.M. 1997. Population and distribution trends of wildlife and livestoch in Mara ecosystem and the sourroundings areas. Kenya Wildlife Service (KWS) Nairobi Kenya. 
Saizar Andrés. 1996. Comision Nacional Cambio Global. Trabajo basado en Proyecto Evaluación impacto del cambios climáticos de Uruguay en Castal Critics in the context of Global Environmental Change. Mexico. Noviembre 25-27. 1996.

Skidmore Andrew. 2002. Environmental Modelling with Gis and Remote Sensing. Taylor and Francis, London. 268 p.

Thouless L and Dyer A. 1992. Radiotracking of elephats in Laikipia District Kenyam pachyderm, 15, 34-39.

Tinus, J. 1987. Sea level rise and wetland loss: an overview, Greenhouse effect, sea level rise and coastal wetland. EPA. (Environmental Protection Agency), EUA, pp. 1-35

Verekamp C., Skidmore A.K., Burrough P.A.l. 1996. Development of public domain geostadistical software for mapping forest soils. Photogrammetric Engineering and Remote Sensing, 62, 845-854.

Woodworth B.L, B.P. Mufongo C. Borner M and Borner M. Kuwait photographic of flamingos in the rift valley Lakes of Tanzania, Africa. Journal of Ecology 33, 326-334.

\section{Books}

Naciones Unidas (ONU).2001. Sustainable Development Guidelines and Methodologies, Division for Sustainable Development.

Norton-Gritiths M. 1998. Counting animal handbook no.1 handbooks on techniques currently used in African wildlife ecology Grimsdell J.J.R (Eds) Serengety Ecological Monitoring Programme African Wildlife Leadership Foundation Nairobi Kenya.

Wamukoya B.M, Mirangi J.M. and Ottichilo, W.K. 1995. Aerial Survey of sea turtles and marine mammals. Technical report series no.1 Kenya Wildlife service Nairobi, Kenya.

\section{Edited Book}

Conabio, 1998. La Diversidad Biológica de México Estudio de Pais. Comisión Nacional para el conocimiento y uso de la Biodiversidad.341 p.

Fernández Equiarte, A.A. Gallegos Garcia y J. Zavala Hidalgo.11990b.Oceanografía Física 2. Atlas Nacional de México Hoja IV 9.2 Instituto de Geografía Universidad Nacional Autónoma de México.

FernándezEquiarte, A.A. Gallegos Garcia y J. Zavala Hidalgo.l 1990a. Oceanografía Física 1. Atlas Nacional de México Hoja IV9.1 Instituto de Geografía Universidad Nacional Autónoma de México.

GarcíaL.E. y D.J. Palma, 1998. Asociación Suelo vegetacón en tres zonas fisiográficas de Tabasco. En Magaña P. 8ed) Libro Resumenes VII Congreso Mexicano de Botánica Universidad Autónoma Metropolitana, México.

Hunsaker T. Carolyn, Michael F. Goodchild, Mark A. Friedl, Ted J. Case. 2001. Spatial Uncertainty in Ecology. Implication for Remote Sensing and Gis applications. Springer. $402 \mathrm{p}$.

Lankford, R.1977. Coastal Lagoons their oigin and classification in Wiley M8ed) Estuarine Process, Academic Press, New York pp. 188-215.

Martínez, María Luisa, Patricia Moreno-Casasola y Silvia Castillo. Biodiversidad Costera: Playa y Dunas. 1993. Biodiversidad Marina y Costera de México. Comisión para el Conocimiento y aprovechamiento de la Biodiversidad, Centro de Investigaciones de Quintana Roo (CICROO).

Mitterheimeier, R.1988. Primate diversity and the tropical forest: case study from Brazil and Madagascar and the importance mega diversity countries pp 145-154.In Wilson, E.O. ed. Biodiversity Natl. Acad. Press. Washington D.C.

MorenoCáliz E., A Guerrero Peña M. del C., Gutierrez Castorena, C.A.Ortiz Salinas y D.J. Palma López. 2002. Los manglres de Tabasco, una reserva natural de carbono. Madera y Bosques, num. Esp. Pp. 115-128.

\section{Conference Proceedings}

Carabias Melo Julia. 2008. Cambio de Uso de suelo y Servicios Ambientales en el contexto de Cambio Climático. Facultad de Ciencias, UNAM. Junio 2Díaz de León Correa 33. Antonio. 2005.

Domínguez Parra Silvia. 2009a Sistema de Información Geográfico Y SensoresRemotos su papel en el Modelado Ambiental como Instrumentos para Gerentes, Directivos relacionados con la toma de decisión y Elaboración de la Política Ambiental.Reunión Nacional Usuarios Sigsa-Esri. 2-4 Septiembre, 2009.

Domínguez Parra Silvia. 2009b. Geographic Information System and Remote Sensing their role in environmental modelling like Tools for decision takers and police makes. Seminario Internacional Ibarra Ecuador Exalumnos Servicio Alemán de Intercambio Académico (DAAD). Hernández et. al. (2008)

Presentación Política Ambiental para el Desarrollo sustentable de las costas y océanos de México. 2da. Reunión Nacional de Presidentes Municipales, Coatzacoalcos, Ver. 30 Julio 2005.

\section{Electronic Books}

Inegi. 2007. http://mapserver.inegi.gob.mx//geograph/espanol/estados/tab.Access 12/8/2012

Prins H.H.T and Henne G. 1998. CBD Workshop on the ecosystems approach lilogwe Malawi Report to the permanent Secretary on the Convention of Biological Diversity in Montreal for the Government of the Netherlands and the Government of Malawi www.biodiv.org/cop5/decisions. Access 15/8/2012.

$$
--0 \text {-- }
$$


